[Article]

\title{
以油酸为原料的新型生物基支链十七烷基苯磺酸钠的合成及性质
}

\author{
市鹏程 ${ }^{1} \quad$ 张大鹏 $^{1}$ 刚洪泽 ${ }^{1} \quad$ 刘金峰 $^{1}$ 牟伯中 ${ }^{1,2}$ 杨世忠 ${ }^{1, *}$ \\ (1华东理工大学应用化学研究所, 生物反应器工程国家重点实验室, 上海 200237; \\ 2上海生物制造技术合作创新中心，上海 200237)
}

\begin{abstract}
摘要: 生物基表面活性剂由于其可再生资源和优异的表面/界面性质吸引了越来越多的关注。本文以可再生 的油酸为原料, 通过四步反应, 制备了新型生物基支链表面活性剂, 并评价了其表/界面性质、润湿性和生 物降解性能。该新型生物基支链表面活性剂为4-(1-十七烷基)苯磺酸钠(9DC17S), 依次经过烷基化反应、脱 羧反应、磺化反应和中和反应而制得。其化学结构已通过电喷雾质谱、红外光谱和核磁共振波谱得以确认。 4-(1-十七烷基)苯磺酸钠展现出良好的表/界面张力, 临界胶束浓度(CMC)为 $317.5 \mathrm{mg} \cdot \mathrm{L}^{-1}, \mathrm{CMC}$ 处的表面张 力为 $32.54 \mathrm{mN} \cdot \mathrm{m}^{-1}$, 当水溶液中碳酸钠浓度为 $8.48 \times 10^{4} \mathrm{mg} \cdot \mathrm{L}^{-1} 、 4-(1$-十七烷基) 苯磺酸钠浓度为 $8.36 \times$ $10^{4} \mathrm{mg} \cdot \mathrm{L}^{-1}$ 时, 油水的界面张力约为 $10^{-2} \mathrm{mN} \cdot \mathrm{m}^{-1}$ 。此外, 4-(1-十七烷基)苯磺酸钠在生物降解性和润湿性方 面也显示出了良好的性能, 最终生物降解评分为 $2.99,0.500 \mathrm{~g} \cdot \mathrm{L}^{-1}$ 9ФC $17 \mathrm{~S}$ 溶液的气液固接触角为 $63.08^{\circ}$ 。该新型生物基表面活性剂丰富了以可再生资源为原料的生物基表面活性剂的结构多样性。
\end{abstract}

关键词：生物基表面活性剂；支链十七烷基苯磺酸钠；脱羧；油酸；可再生资源 中图分类号: 0647

\section{Synthesis and Properties of a Novel Bio-Based Branched Heptadecylbenzene Sulfonate Derived from Oleic Acid}

\author{
BIAN Peng-Cheng ${ }^{1} \quad$ ZHANG Da-Peng ${ }^{1} \quad$ GANG Hong-Ze ${ }^{1} \quad$ LIU Jin-Feng ${ }^{1}$ \\ MU Bo-Zhong ${ }^{1,2} \quad$ YANG Shi-Zhong, \\ ('State Key Laboratory of Bioreactor Engineering and Institute of Applied Chemistry, East China University of Science and \\ Technology, Shanghai 200237, P. R. China; ${ }^{2}$ Shanghai Collaborative Innovation Center for \\ Biomanufacturing Technology, Shanghai 200237, P. R. China)
}

\begin{abstract}
Bio-based surfactants have attracted increasing attention because they are made from renewable resources and have excellent surface/interfacial properties. In this study we prepared a novel bio-based branched alkylbenzene sulfonate surfactant by a four-step route using renewable oleic acids as starting materials. We evaluated the surface behavior, wettability, and biodegradability of our surfactant. The surfactant, 4-(1-heptadecyl) benzene sodium sulfonate (9ФC17S), was synthesized using a facile four-step route involving alkylation, decarboxylation, sulfonation and neutralization, respectively. The chemical structure of 4-(1heptadecyl) benzene sodium sulfonate was confirmed by infrared (IR) spectroscopy, electrospray ionization high resolution mass spectrometry (ESI HRMS) and ${ }^{1} \mathrm{H}$ nuclear magnetic resonance ('H NMR) spectroscopy. The surfactant demonstrated an excellent surface tension of $32.54 \mathrm{mN} \cdot \mathrm{m}^{-1}$ at the critical micelle concentration (CMC) of $317.5 \mathrm{mg} \cdot \mathrm{L}^{-1}$ and outstanding interfacial tension of $\sim 10^{-2} \mathrm{mN} \cdot \mathrm{m}^{-1}$ at $8.36 \times 10^{4} \mathrm{mg} \cdot \mathrm{L}^{-1}$ with $8.48 \times$
\end{abstract}

Received: May 23, 2016; Revised: August 17, 2016; Published online: August 23, 2016.

*Corresponding author. Email: meor@ecust.edu.cn; Tel: +86-21-64252063.

The project was supported by the National Natural Science Foundation of China (51574125, 21203063), National High Technology Research and Development Program of China (2013AA064403), and Foundation of the Ministry of Education of China for Outstanding Young Teachers in University (WJ1514313).

国家自然科学基金(51574125, 21203063), 国家高技术研究发展计划项目(863)(2013AA064403)及国家教育部高等学校优秀青年教师研究基金 (WJ1514313)资助

(c) Editorial office of Acta Physico-Chimica Sinica 
$10^{4} \mathrm{mg} \cdot \mathrm{L}^{-1} \mathrm{Na}_{2} \mathrm{CO}_{3}$. The surfactant also showed good biodegradability with an ultimate biodegradation score of 2.99. The surfactant had good wettability with an air/water/solid contact angle $\left(\theta_{\text {average }}\right)$ of $63.08^{\circ}$ for a 0.500 $\mathrm{g} \cdot \mathrm{L}^{-1}$ 9ФC17S solution. This novel bio-based branched surfactant contributes to the structural diversity of biobased surfactants from renewable feedstock.

\section{Key Words: Bio-based surfactant; Branched heptadecylbenzene sulfonate; Decarboxylation; Oleic acid; Renewable feedstock}

\section{Introduction}

Traditional alkylbenzene sulfonates are a class of petroleumbased surfactants and have been widely used in many industries such as washing ${ }^{1}$, oil recovery ${ }^{2-4}$, pesticide chemistry ${ }^{5,6}$, papermaking ${ }^{7}$, etc. Most of the petroleum-based alkylbenzene sulfonates used in industries were a mixture of linear and branched alkylbenzene sulfonates. Recent studies indicated that the branched alkylbenzene sulfonates performed more outstanding interfacial activities than that of the linear ones ${ }^{8-10}$, and a great effort has been made in synthetic methods of the branched alkylbenzene sulfonate surfactants and in performance evaluations by both the experiment and computer simulations. Yang et al. ${ }^{11,12}$ investigated interfacial behaviors of the three isomers of hexadecylbenzene sulfonates with the benzene ring at different site along the alkyl chain, and the surfactant molecule with a phenyl group near the center of the alkyl chain showed the best result with a reduction of the interfacial tension to ultra-low values at low alkali concentrations. The experimental results suggested that the alkylbenzene sulfonate with a phenyl group in the middle of hydrocarbon chain contributed to the lower surface tension compared to those with a phenyl group in the end of hydrocarbon chains ${ }^{11,12}$, which was coincident with the results of computer simulation ${ }^{13-15}$. However, most of the reported synthesis routes of alkylbenzene sulfonate isomers with the phenyl group at a specific site of hydrocarbon chains were considerably complicated, which has been a block for further development and application of branched alkylbenzene sulfonate surfactants in industries.

Bio-based surfactants have received increasing attention from industrial and scientific fields, due to their renewable resource, outstanding physicochemical property, and low costs ${ }^{16}$. Bio-based surfactants were mainly using biomass as their raw materials, such as carbohydrates ${ }^{17}$, proteins $^{18}$, and vegetable oils ${ }^{19}$, which inherited harvestable sustainability, high output capability, and environmental compatibility. Biomass was seen as one of the best substitutes to petroleum chemicals to be used as alternative resources of surfactants ${ }^{20,21}$. The oleic acid, obtained by hydrolyzation of vegetable oils, was one of the most common kinds in biomass and has attracted great interests as platform chemicals for surfactants. Oleic acids have been applied to produce cationic gemini surfactants, which showed better surface properties than that of similar commercial surfactants ${ }^{22}$. However, the knowledge about oleic acid-based and branched alkylbenzene sulfonates and their application are still limited.

In the present study, the 4-(1-heptadecyl) benzene sodium sulfonate (9ФC17S), a novel bio-based branched heptadecylbenzene sulfonate surfactant was synthesized using renewable oleic acids as starting material by a strategy of a facile four-step route. The chemical structure of the 4-(1-heptadecyl) benzene sodium sulfonate was determined by Fourier transform infrared (FT- IR) spectra, electrospray ionization high resolution mass spectrometry (ESI HRMS), and ${ }^{1} \mathrm{H}$ nuclear magnetic resonance ( ${ }^{1} \mathrm{H}$ NMR) spectra, and its surface behavior, wettability, and biodegradibility were evaluated in this paper.

\section{Materials and methods}

\subsection{Materials}

The oleic acid (AR) was purchased from Tokyo Chemical Industry Co., Ltd, Tokyo, Japan. $\mathrm{AlCl}_{3}(99 \%)$ was purchased from Aladdin, Shanghai, China. $\mathrm{NiCl}_{2} \cdot 6 \mathrm{H}_{2} \mathrm{O}$ (AR), methanol (AR), and ethanol (AR) were purchased from Sinopharm Chemical Reagent Co., Ltd, Shanghai, China. Benzene (AR), $\mathrm{MgCl}_{2} \cdot 6 \mathrm{H}_{2} \mathrm{O}$ (AR), $\mathrm{AlCl}_{3} \cdot 6 \mathrm{H}_{2} \mathrm{O}(\mathrm{AR})$, carbamide (AR), $n$-hexane (AR), sulfuric acid (AR), fuming sulfuric acid (AR), phosphorus pentoxide (AR) and sodium hydroxide (AR) were purchased from Shanghai Lingfeng Chemical Reagent Co., Ltd, Shanghai, China. All the materials were used without further purification.

\subsection{Chemical analyses}

Gas chromatography mass spectrometry (GC-MS) was recorded on Agilent 6890N Network GC system and 5978 inter Mass Selective Detector. Infrared spectra were recorded on a Nicolet iS10 FT-IR spectrometer. Electrospray ionization high resolution mass spectrometry was recorded on the Waters LCT Premier XE Mass Spectrometers. ${ }^{1} \mathrm{H}$ nuclear magnetic resonance spectra were recorded on a Bruker Advance 400 spectrometer (400 MHz) in $\mathrm{D}_{2} \mathrm{O}$ at room temperature. Tetramethylsilane (TMS) was used as reference.

\subsection{Synthetic methods}

The branched heptadecylbenzene sulfonate was synthesized from oleic acid through four steps including the alkylation of benzene, catalyzed decarboxylation, sulfonation and neutralization.

\subsubsection{Alkylation}

The phenyl stearic acid was prepared in the presence of anhydrous $\mathrm{AlCl}_{3}$ by the Friedel-Crafts reaction of oleic acids with benzene in a flask, in which the molar ratio of oleic acid, benzene and anhydrous $\mathrm{AlCl}_{3}$ was $1: 5: 1$. The mixture was heated to $65{ }^{\circ} \mathrm{C}$ and maintained for $6 \mathrm{~h}$ with stirring. The resulted mixtures were then cooled to $0{ }^{\circ} \mathrm{C}$, and equal volume of $6 \mathrm{~mol} \cdot \mathrm{L}^{-1} \mathrm{HCl}$ was added slowly into the flask. The organic layer was seperated and 
evaporated under reduced pressure to obtain phenyl stearic $\operatorname{acid}^{23}$.

\subsubsection{Decarboxylation}

The catalyst, $\mathrm{MgO}-\mathrm{Al}_{2} \mathrm{O}_{3}-\mathrm{NiO}$, was prepared by $\mathrm{MgCl}_{2} \cdot 6 \mathrm{H}_{2} \mathrm{O}$, $\mathrm{AlCl}_{3} \cdot 6 \mathrm{H}_{2} \mathrm{O}, \mathrm{NiCl}_{2} \cdot 6 \mathrm{H}_{2} \mathrm{O}$, and carbamide, in which the molar ratio of $\mathrm{MgO}-\mathrm{Al}_{2} \mathrm{O}_{3}-\mathrm{NiO}$ was $16: 5: 4^{24}$. The catalyst was prepared by homogeneous precipitation method ${ }^{25}$. The prepared catalyst was calcined at $550{ }^{\circ} \mathrm{C}$ for $3 \mathrm{~h}$ and then cooled down to room temperature.

The decarboxylation reaction was carried out in a batch mode operating autoclave reactor $(70 \mathrm{~mL})$, which was designed for operation up to $40 \mathrm{MPa}$ and $350^{\circ} \mathrm{C}$. The reactor was equipped with a multi-blade impeller to mix liquid reactants and solid catalyst. In a typical batch experiment, $20.0 \mathrm{~g}$ of phenyl stearic acid and a series of given quality of catalyst (reactant/catalyst mass ratio: 40/1, 20/1, 10/1) was placed in the reactor. The reactor was then flushed with nitrogen to remove oxygen. Next, the reactions were carried out at a high temperature $\left(150,180,210^{\circ} \mathrm{C}\right)$. The reactor was subsequently cooled down to room temperature. The liquid products were collected after filtering solid catalysts.

\subsubsection{Sulphonation and neutralization}

The heptadecylbenzene was sulfonated with $\mathrm{SO}_{3}$ provided by the reaction of fuming sulfuric acid and phosphorus pentoxide and then neutralized with sodium hydroxide to obtain the final compounds ${ }^{26}$. The mixture was deoiled with normal hexane and desalted in anhydrous ethyl alcohol respectively. The final products were purified by recrystallization in three times with ethanol solution (ethanol/water volume ratio: 1/1).

\subsection{Measurements of surface tensions}

Surface tensions (SFT) were measured by a DCAT 21 surface tensiometer using the plate method at $(25.0 \pm 0.1){ }^{\circ} \mathrm{C}$. Aqueous solutions of samples were prepared with double distilled water. Each surface tension value was evaluated as the average of at least three replicate measurements. The critical micelle concentration (CMC) was obtained from the break point of the curve of surface tension versus concentration.

Maximum surface excess at CMC $\left(\Gamma_{\max }\right)$ was derived from the Gibbs adsorption isotherm equation ${ }^{27}$ :

$$
\Gamma_{\max }=-\frac{1}{2.303 \eta R T}\left(\frac{\partial S F T}{\partial \lg C}\right)_{T}
$$

where $R=8.314 \mathrm{~J} \cdot \mathrm{mol}^{-1} \cdot \mathrm{K}^{-1}, T$ is the absolute temperature, ( $\partial S F T /$ $\partial \lg C)_{T}$ is the slope of the surface tension- $\log$ concentration curve at temperature $T, \eta$ (the number of species at the interface) is taken as 1 for the alkyl benzene sulfonate. The minimum area per molecule occupied at $\mathrm{CMC}, A_{\min }$ was calculated from the relationship with maximum surface excess $\Gamma_{\max }{ }^{27}$.

$$
A_{\text {min }}=\left(N_{\mathrm{A}} \Gamma_{\max }\right)^{-1} \times 10^{16}
$$

where $N_{\mathrm{A}}$ is the Avogadro constant.

\subsection{Measurements of interfacial tensions}

Surfactant solutions were prepared at different concentrations from 0.10 to $0.80 \mathrm{~g} \cdot \mathrm{L}^{-1}$ with Daqing oil field simulated formation water. Interfacial tensions (IFT) were measured by the spinningdrop method using SVT 20 tensiometer at $(50.0 \pm 0.1){ }^{\circ} \mathrm{C}$. Daqing crude oil was used as oil phase.

\subsection{Measurement of the Krafft point temperature}

The conductivities of $1.0 \%$ surfactant solution at different temperatures were measured with a DDSJ-308A conductivity meter, and the Krafft point temperature was obtained at the temperature of the break point of the curve of conductivity versus temperature ${ }^{28}$.

\subsection{Measurement of the HLB value}

The hydrophilic-lipophilic balance (HLB) value of the surfactant was computed by a formula

$$
\mathrm{HLB}=A \times \lg (\mathrm{CMC})+B
$$

where $A=1.961$ and $B=16.235$ for the sodium sulfonate surfactants ${ }^{29}$.

\subsection{Measurement of contact angles}

The contact angles were measured by sessile drop technique for $0.500 \mathrm{~g} \cdot \mathrm{L}^{-1}$ surfactant solution at $25.0{ }^{\circ} \mathrm{C}^{30}$. The measurements were repeated 5 times and the average value was calculated.

\subsection{Prediction of ultimate biodegradation}

The ultimate biodegradation of surfactant was performed using the EPI Suite, BIOWIN3 biodegradation model, which is frequently applied for the degradation estimate of organic chemicals ${ }^{31}$.

\section{Results and discussion}

\subsection{Yields and structural analyses}

The strategy route for synthesis of the bio-based branched alkylbenzene sulfonate was shown in Scheme 1. The branched heptadecylbenzene sulfonate was synthesized from oleic acids and intermediate products were detected by GC-MS after esterification. The GC spectrograms of methyl oleate, phenyl methyl stearate, heptadecylbenzene were shown in Fig.1, in which peaks A, B, C, and D indicated the methyl oleate, methyl stearate, phenyl methyl stearate, and heptadecylbenzene, respectively. Line 1 showed the products of esterification of oleic acid samples. There was little stearic acid in this sample, which could be used as the internal standard for the calculation of yields of Friedel-Crafts reaction. Line 2 indicated the result of Friedel-Crafts reaction of oleic acids. It showed that the oleic acid was completely expended

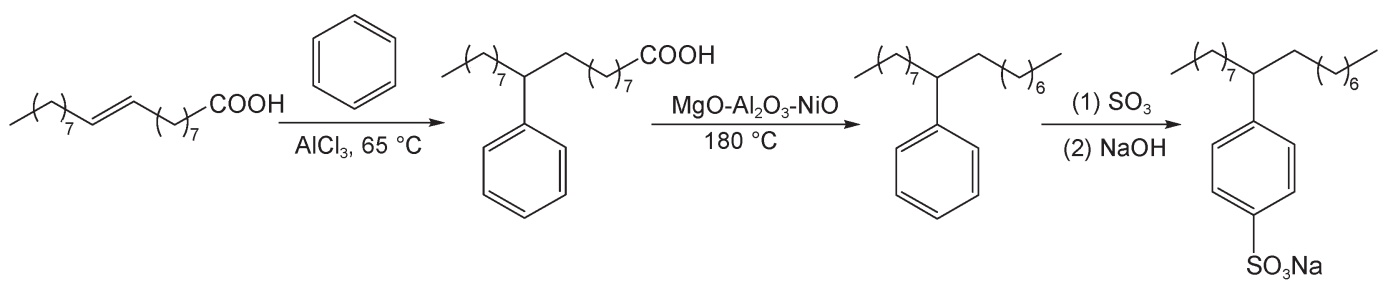

Scheme 1 Strategy route for synthesis of the bio-based branched alkylbenzene sulfonate 

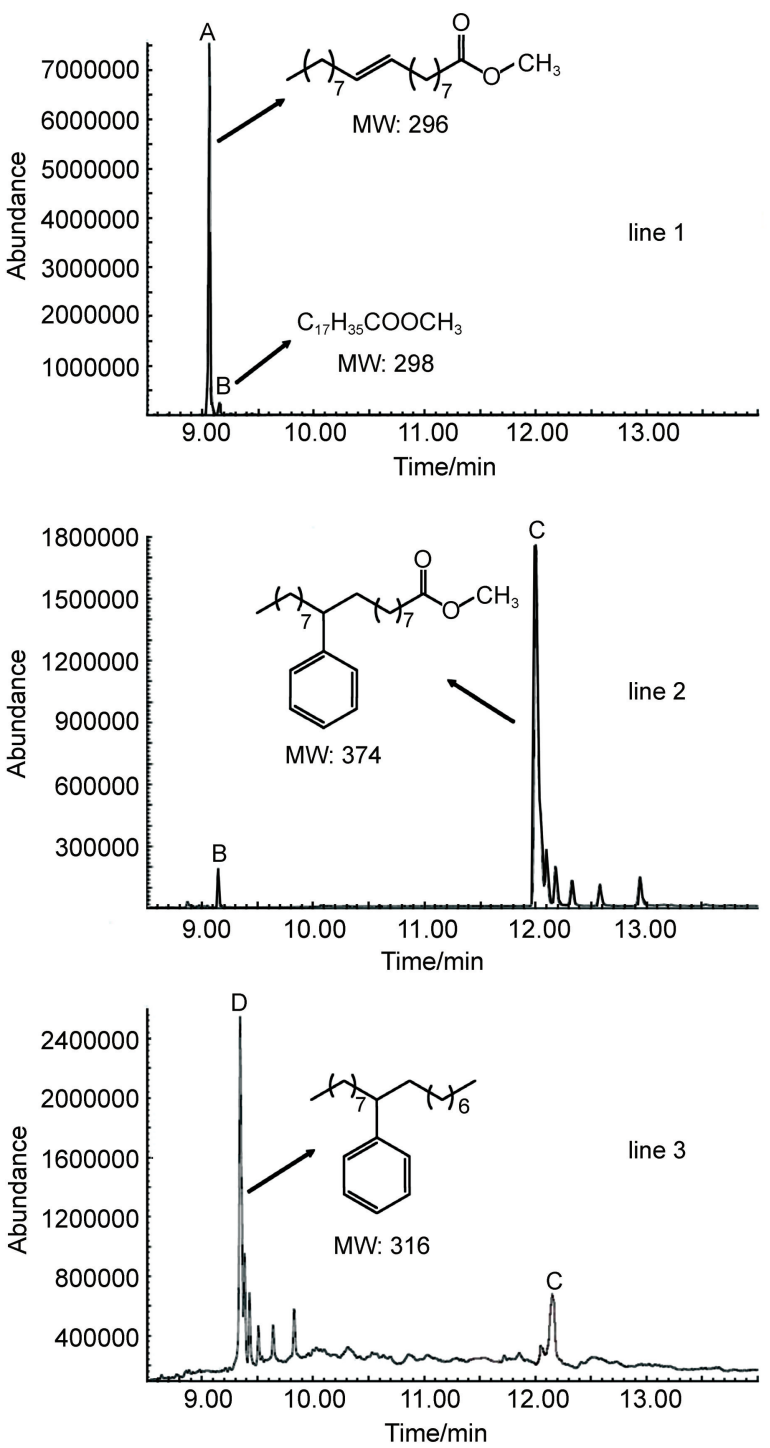

Fig.1 GC spectrogram of the methyl oleate, phenyl methyl stearate, and heptadecylbenzene line 1: the products of esterification of oleic acid sample; line 2: the result of Friedel-Crafts reaction of oleic acid; line 3: the result of decarboxylation of phenyl stearic acid

from the comparison with line 1 , and it yielded $97.7 \%$ in the Friedel-Crafts reaction. The GC spectrogram of decarboxylation of phenyl stearic acid was shown in line 3 . The yield of decarboxylation reaction was $93.2 \%$, as shown for the number 6 in Table 1 . The reactions of sulfonation and neutralization of heptadecylbenzene carried out with $\mathrm{SO}_{3}$ yielded about $77.9 \%$ by weighing method.

The molecular weight (MW) of 9ФC17S was determined by ESI HRMS and the ionization way of ESI HRMS was negative ion mode without $\mathrm{Na}^{+}$. The mass-to-charge ratio $(\mathrm{m} / \mathrm{z})$ of the main peak was 395.3, as shown in Fig.2. For a further structral analysis the FT-IR and ${ }^{1} \mathrm{H}$ NMR were applied. It indicated in ${ }^{1} \mathrm{H}$ NMR spectral pattern (as Fig.S1 shown in the Supporting Information) that the hydrogen atoms in the surfactant were identified according to their chemical environment using ${ }^{1} \mathrm{H}$ NMR. The signals at 0.79
Table 1 Design and optimum conditions of decarboxylation of phenyl stearic acid

\begin{tabular}{ccccc}
\hline Number & $t / \mathrm{h}$ & Stirring speed $/\left(\mathrm{r} \cdot \mathrm{min}^{-1}\right)$ & Reactant/Catalyst mass ratio & Yield/\% \\
\hline 1 & 6 & 150 & $20: 1$ & 3.9 \\
2 & 6 & 150 & $20: 1$ & 93.5 \\
3 & 3 & 150 & $10: 1$ & 21.1 \\
4 & 3 & 300 & $20: 1$ & 60.9 \\
5 & 3 & 450 & $40: 1$ & 56.8 \\
6 & 6 & 150 & $20: 1$ & 93.2 \\
7 & 6 & 300 & $40: 1$ & 70.8 \\
8 & 6 & 450 & $10: 1$ & 57.2 \\
9 & 9 & 150 & $40: 1$ & 65.1 \\
10 & 9 & 300 & $10: 1$ & 47.0 \\
11 & 9 & 450 & $20: 1$ & 62.8 \\
\hline
\end{tabular}

Numbers 1 and 2 were carried out at 150 and $210^{\circ} \mathrm{C}$, respectively. Numbers 3-11 were performed at $180{ }^{\circ} \mathrm{C}$.

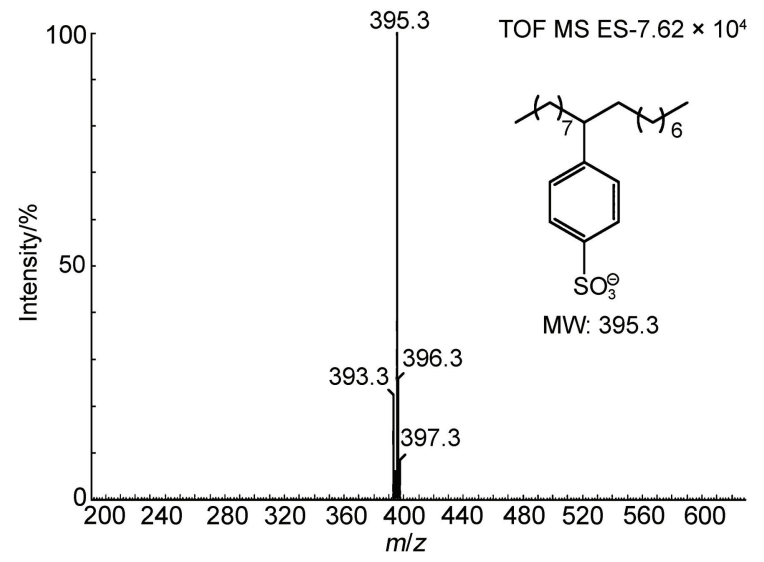

Fig.2 ESI HRMS spectrum of 9ФC17S

and 1.16 were attributed to the hydrogen atoms on the end methyl and methylene of the long carbon chains, respectively. Peaks at 1.49 indicated the hydrogen atoms in $-\mathrm{CH}_{2}-\mathrm{CH}-\mathrm{C}_{6} \mathrm{H}_{4}-$. And the resonance of the hydrogen atom neighboring the benzene rings was 2.39. The signals at 7.16-7.65 were assigned to the resonances of the benzene ring. In the FT-IR spectrogram (Fig.S2 shown in the Supporting Information), the peaks at 2961.76 and $2858.59 \mathrm{~cm}^{-1}$ suggested the absorbance of methylene and methyl groups in the carbon chain. The absorbance wavelengths of the benzene ring were 1650.62 and $1467.25 \mathrm{~cm}^{-1}$. And the peaks at $1186.30,1129.80,1043.35 \mathrm{~cm}^{-1}$ indicated the absorbance of $\mathrm{S}=$ O double bond.

In general routes for synthesis of the branched alkylbenzene sulfonates there included at least 8 steps $^{11,12}$. However, in this study a novel bio-based branched alkylbenzene sulfonate was synthesized by a strategy of only four-step route as shown in Sheme 1, which was more simple and convenient. In addition, the starting material used in this synthetic method was oleic acids, a class of renewable resources from oils, or even waste cooking oils.

\subsection{Optimization of decarboxylation}

The yields in different conditions for the optimization were shown in Table 1 . The numbers 1, 2, 6 were carried out at 150 , 
210 , and $180{ }^{\circ} \mathrm{C}$, respectively, in which the yields were $3.9 \%$, $93.5 \%$, and $93.2 \%$, respectively. Numbers 3-11 were performed at $180{ }^{\circ} \mathrm{C}$ using an optimization design method with various conditions, including reaction time, the stirring speed and the ratio of reactant to catalyst. And the yields were also listed. Number 6 suggested the optimized result for the decarboxylation reaction. Besides, the mass spectrum of the product was shown in Fig.S3 (Supporting Information).

The Friedel-Crafts reaction and sulfonation have been extremely studied in the synthesis of alkylbenzene sulfonate, compared to the decarboxylation. Herein, the decarboxylation was researched with the catalyst $\mathrm{MgO}-\mathrm{Al}_{2} \mathrm{O}_{3}-\mathrm{NiO}$ by optimization method. In the recent research about decarboxylation, the reaction temperature was $200{ }^{\circ} \mathrm{C}$ for fatty acids with $\mathrm{Pd} / \mathrm{C}$ catalyst ${ }^{32}$, the temperature was $400{ }^{\circ} \mathrm{C}$ for microalgal oil with $\mathrm{MG} 63^{33}$, and the temperature of decarboxylation of oleic acid with $\mathrm{Ni} / \mathrm{MgO}-\mathrm{Al}_{2} \mathrm{O}_{3}$ was $300{ }^{\circ} \mathrm{C}^{24}$. With the MG63 or $\mathrm{Ni} / \mathrm{MgO}-\mathrm{Al}_{2} \mathrm{O}_{3}$ catalyst, the temperature for decarboxylation was higher, which implied that the reaction would need more energy consumption. However, in our study, with the catalyst $\mathrm{MgO}-\mathrm{Al}_{2} \mathrm{O}_{3}-\mathrm{NiO}$, the reaction of decarboxylation was carried out completely under the condition of $180^{\circ} \mathrm{C}$, the number 6 as shown in Table 1. This temperature was much lower, while the yield with the catalyst $\mathrm{MgO}-\mathrm{Al}_{2} \mathrm{O}_{3}-\mathrm{NiO}$ was $93.2 \%$, as high as that in reaction with $\mathrm{Pd} / \mathrm{C}$ catalyst.

However, when the temperature of decarboxylation reaction was below $180{ }^{\circ} \mathrm{C}$, for example, $150{ }^{\circ} \mathrm{C}$, the productivity was very low (only $3.9 \%$ ). On the other hand, when the temperature was above $180^{\circ} \mathrm{C}$, such as $210^{\circ} \mathrm{C}$, there was not obvious improvement for the productivity (yield 93.5\%). Consequently, an optimization design method was proposed with various conditions as numbers $3-11$, and the optimum conditions for the decarboxylation reaction was $150 \mathrm{r} \cdot \mathrm{min}^{-1}$ of stirring speed, $20: 1$ for reactant/catalyst and $6 \mathrm{~h}$.

\subsection{Surface properties}

The surface tension as a function of $9 \Phi C 17 \mathrm{~S}$ concentrations at $25.0^{\circ} \mathrm{C}$ was illustrated in Fig.3. The CMC and the surface tension at $\mathrm{CMC}\left(\mathrm{SFT}_{\mathrm{CMC}}\right)$ were obtained from the breakpoint of the plot

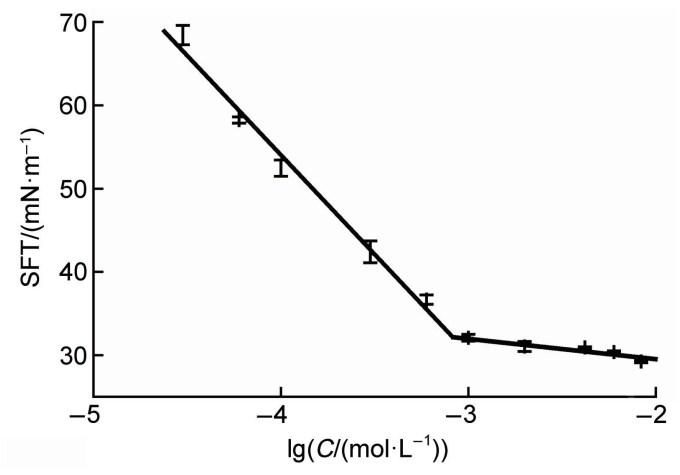

Fig.3 Variation of the surface tensions with the concentrations of $9 \Phi \mathrm{C} 17 \mathrm{~S}$ at $25.0{ }^{\circ} \mathrm{C}$ in Fig.3. The surface excess $\left(\Gamma_{\max }\right)$ and the area occupied per surfactant molecule $\left(A_{\min }\right)$ at CMC on air/water interface were computed by Eqs.(1) and (2), respectively. It showed in Fig.3 that 9ФC17S presented a sharp break corresponding to CMC of 317.5 $\mathrm{mg} \cdot \mathrm{L}^{-1}$ with $\mathrm{SFT}_{\mathrm{CMC}}=32.54 \mathrm{mN} \cdot \mathrm{m}^{-1}$ at $25^{\circ} \mathrm{C}$, and the calculated minimum surface area per molecule for $9 \Phi C 17 \mathrm{~S}$ was $0.39 \mathrm{~nm}^{2}$, as summarized in Table 2 . The CMC by electrical conductivity was $304.5 \mathrm{mg} \cdot \mathrm{L}^{-1}$ from Fig.S4 (Supporting Information), similar to that by a surface tension method. The relative deviation between them was $4.3 \%$.

\subsection{Interfacial properties}

Fig.4 showed the dynamic interfacial tensions (DIFT) between Daqing crude oil and simulated formation water at different concentrations of $9 \Phi C 17 \mathrm{~S}$ solutions measured at $50.0^{\circ} \mathrm{C}$. Fig.4(a) displayed that the equilibrium IFT values were: $2.44,1.65,0.78$, and $1.16 \mathrm{mN} \cdot \mathrm{m}^{-1}$ at the concentrations of $9 \Phi C 17 \mathrm{~S}$ solutions of: $0.10,0.20,0.50$, and $0.80 \mathrm{~g} \cdot \mathrm{L}^{-1}$, respectively. The minimum value of $0.78 \mathrm{mN} \cdot \mathrm{m}^{-1}$ appeared at $0.50 \mathrm{~g} \cdot \mathrm{L}^{-1}$, and the equilibrium IFT value between Daqing crude oil and simulated formation water without surfactants was $9.47 \mathrm{mN} \cdot \mathrm{m}^{-1}$. Fig.4(b), (c), and (d) indicated the dynamic interfacial tensions between Daqing crude oil and $0.10,0.20$, and $0.50 \mathrm{~g} \cdot \mathrm{L}^{-1} 9 \Phi C 17 \mathrm{~S}$ solutions with adding different concentrations of extra $\mathrm{Na}_{2} \mathrm{CO}_{3}$, respectively. All the equilibrium values of DIFT between crude oil and 9ФC17S solutions decreased with the concentration of $\mathrm{Na}_{2} \mathrm{CO}_{3}$ increased. The interfacial tension of $\sim 10^{-2} \mathrm{mN} \cdot \mathrm{m}^{-1}$ was obtained at $0.2 \mathrm{~mol} \cdot \mathrm{L}^{-1}$ with $0.8 \mathrm{~mol} \cdot \mathrm{L}^{-1} \mathrm{Na}_{2} \mathrm{CO}_{3}$. Dynamic interfacial tensions between Daqing crude oil and different concentrations $\mathrm{Na}_{2} \mathrm{CO}_{3}$ solutions in simulated formation water were measured at $50.0^{\circ} \mathrm{C}$, displayed in Fig.S5 (Supporting Information), which suggested that only $\mathrm{Na}_{2} \mathrm{CO}_{3}$ could not decrease IFT to ultralow value in our experiments.

One of the most important applications of alkylbenzene sulfonates was to enhance oil recovery ${ }^{34,35}$. The IFT in $10^{-3} \mathrm{mN} \cdot \mathrm{m}^{-1}$ order of magnitude was critically required for availably displacement of residual crude oil from the capillaries and pores of petroleum reservoirs ${ }^{36}$. To achieved ultra-low IFT value, alkali were widely used accompanying with alkyl benzene sulfonates in oil recovery ${ }^{37}$. The alkali solution could react with acidic components of petroleum to produce in situ surfactants, which may interact with alkyl benzene sulfonates and reduce the IFT value between crude oil and water observably ${ }^{38-40}$. As the IFT value between Daqing crude oil with the 9ФC17S solution were far away from ultra-low IFT value in Fig.4(a), different concentration of $\mathrm{Na}_{2} \mathrm{CO}_{3}$ solution was added into different concentration of 9ФC17S solution (Fig.4(b), (c) and (d)) to achieve lower IFT values. All the minimum values of DIFT were in $10^{-3} \mathrm{mN} \cdot \mathrm{m}^{-1}$ order of magnitude combined with $0.80 \mathrm{~mol} \cdot \mathrm{L}^{-1} \mathrm{Na}_{2} \mathrm{CO}_{3}$, which indicated that $9 \Phi \mathrm{C} 17 \mathrm{~S}$ could be a class of candidate for oil re-

Table 2 Surface properties, HLB value, contact angle, and Krafft point of 9ФC17S

\begin{tabular}{|c|c|c|c|c|c|c|}
\hline $\mathrm{CMC} /\left(\mathrm{mg} \cdot \mathrm{L}^{-1}\right)$ & $\mathrm{SFT}_{\mathrm{cmd}} /\left(\mathrm{mN} \cdot \mathrm{m}^{-1}\right)$ & $10^{-8} \Gamma_{\max } /\left(\mathrm{mol} \cdot \mathrm{m}^{-2}\right)$ & $A_{\min } /\left(\mathrm{nm}^{2} \cdot\right.$ molecule $\left.^{-1}\right)$ & HLB & Contact angle $/\left(^{\circ}\right)$ & Krafft point $/{ }^{\circ} \mathrm{C}$ \\
\hline 317.5 & 32.54 & 4.27 & 0.39 & 10.12 & 63.08 & 58.15 \\
\hline
\end{tabular}



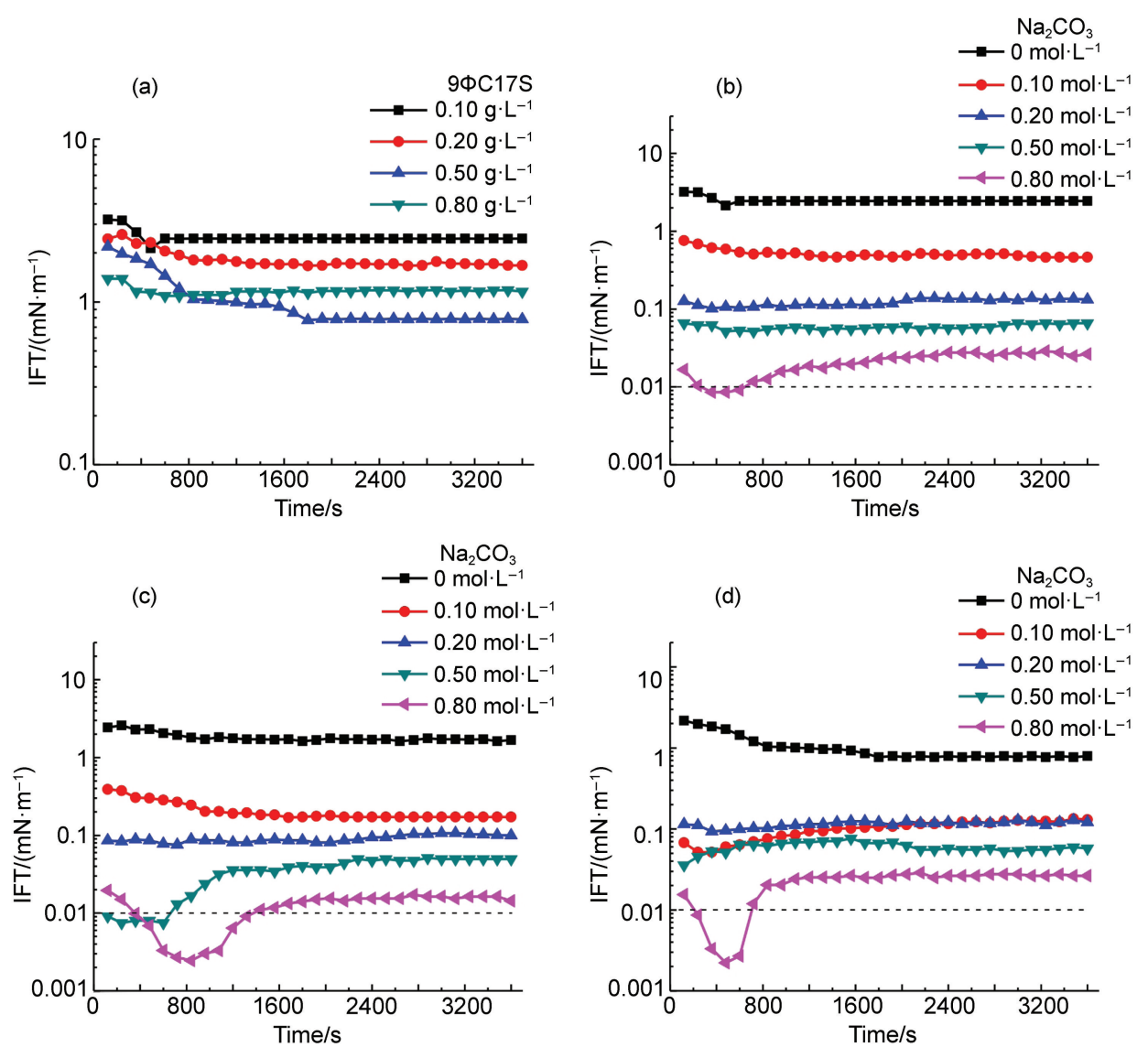

Fig.4 Interfacial properties of $9 \Phi C 17 \mathrm{~S}$ solutions in simulated formation water at $50.0{ }^{\circ} \mathrm{C}$

Dynamic interfacial tensions between Daqing crude oil and $9 \Phi C 17 \mathrm{~S}$ solutions at different $9 \Phi C 17 \mathrm{~S}$ concentrations without $\mathrm{Na}_{2} \mathrm{CO}_{3}(\mathrm{a})$, and at $9 \Phi C 17 \mathrm{~S}$ concentrations of $0.10 \mathrm{~g} \cdot \mathrm{L}^{-1}(\mathrm{~b}), 0.20 \mathrm{~g} \cdot \mathrm{L}^{-1}(\mathrm{c})$, and $0.50 \mathrm{~g} \cdot \mathrm{L}^{-1}$ (d) solutions with adding different concentrations of extra $\mathrm{Na}_{2} \mathrm{CO}_{3}$

covery. Although all the equilibrium values of DIFT between crude oil and 9ФC17S solutions decreased with the concentration of $\mathrm{Na}_{2} \mathrm{CO}_{3}$ increased, these decrement degrees of DIFT equilibrium values were different. The DIFT equilibrium values decreased from 0.460 to $0.026 \mathrm{mN} \cdot \mathrm{m}^{-1}$ in Fig.4(b), and reduced from 0.170 to $0.016 \mathrm{mN} \cdot \mathrm{m}^{-1}$ in Fig. 4 (c) with the $\mathrm{Na}_{2} \mathrm{CO}_{3}$ concentrations increased from 0.10 to $0.80 \mathrm{~mol} \cdot \mathrm{L}^{-1}$. While for the higher $9 \Phi C 17 \mathrm{~S}$ concentration as shown in Fig.4(d), this value reduced to $0.026 \mathrm{mN} \cdot \mathrm{m}^{-1}$ from $0.13 \mathrm{mN} \cdot \mathrm{m}^{-1}$ with the same $\mathrm{Na}_{2} \mathrm{CO}_{3}$ concentration recruitment. It illustrated that the absorbance of surfactant on the oil/water interface did not change coincident with the surfactant concentration in solution, as the dynamic equilibrium value depends on the adsorption of surfactant molecules.

\subsection{Contact angles, HLB values, and the Krafft point}

Table 2 suggested the contact angle $\theta_{\text {average }}$ of air/water/solid was $63.08^{\circ}$ at $0.500 \mathrm{~g} \cdot \mathrm{L}^{-1} 9 \Phi \mathrm{C} 17 \mathrm{~S}$ solutions and the HLB value was 10.12 calculated by Eq.(3). The Krafft point was $58.15^{\circ} \mathrm{C}$ from Fig.S6 (Supporting Information), obtained by the conductivities curve of $1 \%$ surfactant solution under different temperatures, as shown in Table 2 . The average contact angle of double distilled water on the hydrophobic acrylic substrate was $92.04^{\circ}$ at $25.0{ }^{\circ} \mathrm{C}^{19}$. The contact angle results suggested a great wettability of $9 \Phi C 17 \mathrm{~S}$. The HLB value indicated that $9 \Phi C 17 \mathrm{~S}$ was almost balanced in hydrophile-lipophile property and could be used as emulsifier. The Krafft points of $\mathrm{C}_{16} \mathrm{H}_{33} \mathrm{SO}_{3} \mathrm{Na}$ and $\mathrm{C}_{18} \mathrm{H}_{37} \mathrm{SO}_{3} \mathrm{Na}$ were 55.3 and $64.8^{\circ} \mathrm{C}$, respectively, in the previous research ${ }^{41}$. The Krafft point for $9 \Phi C 17 \mathrm{~S}$ in this study was coincident with the previous report due to the relation between Krafft point and molecular structure.

\subsection{Biodegradability prediction}

The ultimate biodegradation score of $9 \Phi C 17 \mathrm{~S}$ was 2.99 . The score above 2.8 was the biodegradation order of "weeks", and scores between 2.0 and 2.8 were in order of "months". This result meant the expected total degradation time was between "weeks", and suggested that $9 \Phi C 17 \mathrm{~S}$ was biodegradable. The ultimate biodegradation scores of normal alkyl benzene sulfonate and alkyl naphthalene sulfonate were $2.59-2.84$ and $2.48-2.73$, respectively ${ }^{19}$. The predicted result of $9 \Phi C 17 \mathrm{~S}$ was higher than that of other surfactants, indicated that the degradation period of $9 \Phi C 17 \mathrm{~S}$ was the shortest, which meant that $9 \Phi C 17 \mathrm{~S}$ was friendly allowable in surfactant's industrial applications.

\section{Conclusions}

In summary the novel bio-based branched surfactant 4-(1heptadecyl) benzene sodium sulfonate $(9 \Phi C 17 \mathrm{~S})$ was synthesized 
from renewable oleic acids using a strategy of a four-step route of the alkylation, decarboxylation, sulfonation and neutralization. The novel bio-based branched alkylbenzene sulfonate showed a $\mathrm{CMC}$ as low as $317.5 \mathrm{mg} \cdot \mathrm{L}^{-1}$ and the higher interfacial activities in aqueous solutions with $\mathrm{Na}_{2} \mathrm{CO}_{3}$. The interfacial tension between crude oil and simulated formation water was greatly reduced to a ultra-low order $\left(\leq 10^{-2} \mathrm{mN} \cdot \mathrm{m}^{-1}\right)$ at $8.36 \times 10^{-4} \mathrm{mg} \cdot \mathrm{L}^{-1} 9 \Phi C 17 \mathrm{~S}$ in solutions, and the prediction of the ultimate biodegradation score (2.99) showed the biodegradation order of "weeks", which suggested that the novel bio-based branched surfactant would be a very competitive candidate in surfactant flooding in oil recovery, and friendly allowable in oil spill treatment and many other industrial applications.

Supporting Information: available free of charge via the internet at http://www.whxb.pku.edu.cn.

\section{References}

(1) Cohen, L.; Moreno, A.; Berna, J. J. Am. Oil Chem. Soc. 1993, 70, 79. doi: 10.1007/BF02641010

(2) Llenado, R. A. Enhanced Oil Recovery. Google Patents: US4565647 A, 1986-01-21.

(3) Shupe, R. D. Surfactant Oil Recovery Process Usable in High Temperature Formations. Google Patents: US4018278 A, 197704-19.

(4) Dai, C.; Wang, K.; Liu, Y.; Li, H.; Wei, Z.; Zhao, M. Energy Fuels 2015, 29, 2304. doi: 10.1021/acs.energyfuels.5b00507

(5) Holmstrup, M.; Krogh, P. H. Environ. Toxicol. Chem. 1996, 15, 1745. doi: 10.1002/etc.5620151013

(6) Nimer, M.; Ballesteros, O.; Navalon, A.; Crovetto, G.; Verge, C.; López, I.; Berna, J.; Vílchez, J. Anal. Bioanal. Chem. 2007, 387, 2175. doi: 10.1007/s00216-006-1069-y

(7) Schultz, W. S.; Beyer, U. Invert Size for the Internal and Surface Sizing of Paper. Google Patents: US4983257 A, 1991-01-08.

(8) Cao, Y.; Zhao, R. H.; Zhang, L.; Xu, Z. C.; Jin, Z. Q.; Luo, L.; Zhang, L.; Zhao, S. Energy Fuels 2012, 26, 2175. doi: 10.1021/ ef201982s

(9) Zhang, L.; Wang, X. C.; Gong, Q. T.; Zhang, L.; Luo, L.; Zhao, S.; Yu, J. Y. J. Colloid Interface Sci. 2008, 327, 451. doi: 10.1016/j.jcis.2008.08.019

(10) Zhao, R. H.; Huang, H. Y.; Wang, H. Y.; Zhang, J. C.; Zhang, L.; Zhang, L.; Zhao, S. J. Dispersion Sci. Technol. 2013, 34, 623. doi: 10.1080/01932691.2012.685844

(11) Zhao, Y.; Li, P.; Li, Z.; Qiao, W.; Cheng, L.; Yang, J. Pet. Sci. Technol. 2007, 25, 1429. doi: 10.1056/NEJMoa1014618

(12) Yang, J.; Qiao, W.; Li, Z.; Cheng, L. Fuel 2005, 84, 1607. doi: 10.1016/j.fuel.2005.01.014

(13) He, X.; Guvench, O.; MacKerell, A. D., Jr.; Klein, M. L. J. Phys. Chem. B 2010, 114, 9787. doi: 10.1021/jp101860v

(14) Jang, S. S.; Lin, S. T.; Maiti, P. K.; Blanco, M.; Goddard, W. A.; Shuler, P.; Tang, Y. J. Phys. Chem. B 2004, 108, 12130. doi: 10.1021/jp048773n

(15) Zhao, T.; Xu, G.; Yuan, S.; Chen, Y.; Yan, H. J. Phys. Chem. B 2010, 114, 5025. doi: 10.1021/jp907438x

(16) Foley, P.; Beach, E. S.; Zimmerman, J. B. Chem. Soc. Rev. 2012, 41, 1499. doi: $10.1039 / \mathrm{C} 1 \mathrm{CS} 15217 \mathrm{C}$

(17) Rajabi, F.; Luque, R. RSC Adv. 2014, 4, 5152. doi: 10.1039/ C3RA45757E

(18) Sreenu, M.; Rao, B. V.; Prasad, R. B. N.; Sujitha, P.; Chityala, G. K. Eur. J. Lipid Sci. Technol. 2014, 116, 193. doi: 10.1002/ ejlt.201300189

(19) Zhang, Q. Q.; Cai, B. X.; Xu, W. J.; Gang, H. Z.; Liu, J. F.; Yang, S. Z.; Mu, B. Z. Colloids Surf. A 2015, 483, 87. doi: 10.1016/j.colsurfa.2015.05.060

(20) Melero, J. A.; Iglesias, J.; Garcia, A. Energy Environ. Sci. 2012, 5, 7393. doi: $10.1039 / \mathrm{C} 2 \mathrm{EE} 21231 \mathrm{E}$

(21) Climent, M. J.; Corma, A.; Iborra, S. Green Chem. 2014, 16, 516. doi: $10.1039 / \mathrm{C} 3 \mathrm{GC} 41492 \mathrm{~B}$

(22) Sakai, K.; Saito, Y.; Uka, A.; Matsuda, W.; Takamatsu, Y.; Kitiyanan, B.; Endo, T.; Sakai, H.; Abe, M. J. Oleo Sci. 2013, 62, 489. doi: 10.5650/jos.62.489

(23) Zhang, Q. Q.; Cai, B. X.; Xu, W. J.; Gang, H. Z.; Liu, J. F.; Yang, S. Z.; Mu, B. Z. Sci. Rep. 2015, 5, 9971. doi: 10.1038/ srep09971

(24) Roh, H. S.; Eum, I. H.; Jeong, D. W.; Yi, B. E.; Na, J. G.; Ko, C. H. Catal. Today 2011, 164, 457. doi: 10.1016/j. cattod.2010.10.048

(25) Ogawa, M.; Kaiho, H. Langmuir 2002, 18, 4240. doi: 10.1021/ la0117045

(26) Ortega, J. A. T.; Aldana, L. A. D.; Castellanos, F. J. S. Ing. Investig. 2009, 29, 48.

(27) Du, X.; Lu, Y.; Li, L.; Wang, J.; Yang, Z. Colloids Surf. A 2006, 290, 132. doi: 10.1016/j.colsurfa.2006.05.013

(28) Guo, Y. J.; Liu, J. X.; Zhang, X. M.; Feng, R. S.; Li, H. B.; Zhang, J.; Lv, X.; Luo, P. Y. Energy Fuels 2012, 26, 2116. doi: 10.1021/ef202005p

(29) Jiahua, Z.; Yingde, C. Special Petrochem. 2001, 2, 004.

(30) Nedyalkov, M.; Alexandrova, L.; Platikanov, D.; Levecke, B.; Tadros, T. F. Colloid. Polym. Sci. 2008, 286, 713. doi: 10.1007/ s00396-007-1823-5

(31) Song, S.; Song, M.; Zeng, L.; Wang, T.; Liu, R.; Ruan, T.; Jiang, G. Environ. Pollut. 2014, 186, 14. doi: 10.1016/j. envpol.2013.11.023

(32) Santillan-Jimenez, E.; Morgan, T.; Lacny, J.; Mohapatra, S.; Crocker, M. Fuel 2013, 103, 1010. doi: 10.1016/j. fuel.2012.08.035

(33) Na, J. G.; Han, J. K.; Oh, Y. K.; Park, J. H.; Jung, T. S.; Han, S. S.; Yoon, H. C.; Chung, S. H.; Kim, J. N.; Ko, C. H. Catal. Today 2012, 185, 313. doi: 10.1016/j.cattod.2011.08.009

(34) Li, Y.; He, X.; Cao, X.; Zhao, G.; Tian, X.; Cui, X. J. Colloid Interface Sci. 2007, 307, 215. doi: 10.1016/j.jcis.2006.11.026

(35) Li, Y.; Zhang, P.; Dong, F. L.; Cao, X. L.; Song, X. W.; Cui, X. 
H. J. Colloid Interface Sci. 2005, 290, 275. doi: 10.1016/j. jcis.2005.04.035

(36) Qiao, W.; Li, J.; Zhu, Y.; Cai, H. Fuel 2012, 96, 220. doi: 10.1016/j.fuel.2012.01.014

(37) Dai, X.; Suo, J.; Duan, X.; Bai, Z.; Zhang, L. J. Surfactants Deterg. 2008, 11, 111. doi: 10.1007/s11743-008-1061-y

(38) Chen, L.; Zhang, G.; Ge, J.; Jiang, P.; Tang, J.; Liu, Y. Colloids Surf. A 2013, 434, 63. doi: 10.1016/j.colsurfa.2013.05.035
(39) Tang, M.; Zhang, G.; Ge, J.; Jiang, P.; Liu, Q.; Pei, H.; Chen, L. Colloids Surf. A 2013, 421, 91. doi: 10.1016/j. colsurfa.2012.12.055

(40) Zhao, X.; Bai, Y.; Wang, Z.; Shang, X.; Qiu, G.; Chen, L. J. Dispersion Sci. Technol. 2013, 34, 756. doi: 10.1080/ 01932691.2012 .686252

(41) Fekarcha, L.; Tazerouti, A. J. Surfactants Deterg. 2012, 15, 419 doi: 10.1007/s11743-012-1335-2

\section{欢迎订阅《物理化学学报》}

2017年全国报刊杂志征订工作已经开始，敬请向贵单位推荐订阅 2017年《物理化学学报》。

《物理化学学报》是由中国科学技术协会主管, 中国化学会和北京大学共同主办, 北京大学化学与分子工程学院学报编 辑部编辑出版的学术刊物。设有 “亮点”、“通讯”、“展望”、“专论”、“综述”、“论文” 等栏目, 报导物理化学学科及交叉 学科的基础研究及应用研究的创新成果。

中国科学院院士唐有祺先生担任名誉主编, 中国科学院院士刘忠范先生担任主编; 编委会中有 12 位两院院士, 2 位美 国科学院院士, 1 位加拿大科学院院士, 10 位海外学者。2004年, 获得国内期刊界最高奖——第三届国家期刊奖百种重点 期刊奖; 入选国家新闻出版广电总局 2015 年 “百强报刊”。中国科协精品科技期刊工程项目资助出版。读者普遍认为《物 理化学学报》具有极高的学术价值和收藏价值。

《物理化学学报》已被美国《科学引文索引》 $(\mathrm{SCI})$ 网络版、美国《化学文献》 $(\mathrm{CA})$ 、日本《科技文献速报》、俄罗斯 《文献杂志》 $(\mathrm{AJ})$ 、中国科协和国家自然基金委主办的《中国学术期刊文摘》、中国科学技术部万方数据网络中心的《中国 科技论文与引文数据库》(CSTPCD)、中国科学院文献情报中心的《中国科学引文数据库》、中国生物学文献数据中心的 《中国生物文摘》等国内外多种著名检索刊物和文献数据库摘引和收录。

《物理化学学报》现为月刊, 大 16 开本, 亚光铜版纸印刷。2017 年订价 50.00 元/册, 全年订价 600.00 元。国内邮发代 号 82-163, 欢迎国内读者到当地邮局订阅, 国外读者可通过中国国际图书贸易总公司订阅(Code No 1443-MO)。若通过邮局 订阅有困难或错过订阅, 请直接与编辑部联系。欢迎广大科技工作者, 科研单位, 高等院校, 图书馆订阅。

地址: 北京大学化学学院《物理化学学报》编辑部

邮编: 100871

电话: $+86-10-62751724$

传真: +86-10-62756388

邮箱: whxb@pku.edu.cn

网址: http://www.whxb.pku.edu.cn 
Supporting Information for Acta Phys. -Chim. Sin. 2016, 32 (11), 2753-2760

doi : $\quad$ 10. 3866/PKU. WHXB201608231

\title{
以油酸为原料的新型生物基支链十七烷基苯磺酸钠的合成 及性质
}

\author{
市鹏程 $^{1} \quad$ 张大鹏 $^{1}$ 刚洪泽 ${ }^{1} \quad$ 刘金峰 $^{1}$ 牟伯中 ${ }^{1,2}$ \\ 杨世忠 1 ,* \\ ( 1 华东理工大学应用化学研究所, 生物反应器工程国家重点实验室, 上海 200237; \\ 2 上海生物制造技术合作创新中心，上海 200237)
}

\section{Synthesis and Properties of a Novel Bio-Based Branched Heptadecylbenzene Sulfonate Derived from Oleic Acid}

\author{
BIAN Peng-Cheng ${ }^{1} \quad$ ZHANG Da-Peng $^{1} \quad$ GANG Hong-Ze $^{1} \quad$ LIU Jin-Feng $^{1}$ \\ MU Bo-Zhong ${ }^{1,2} \quad$ YANG Shi-Zhong ${ }^{1, *}$ \\ ( ${ }^{1}$ State Key Laboratory of Bioreactor Engineering and Institute of Applied Chemistry, East China University of \\ Science and Technology, Shanghai 200237, P. R. China; ${ }^{2}$ Shanghai Collaborative Innovation Center for \\ Biomanufacturing Technology, Shanghai 200237, P. R. China)
}

*Corresponding author. Email: meor@ecust.edu.cn; Tel: +86-21-64252063. 


\section{The condition of GC-MS analyzation}

The gas chromatograph was equipped with a capillary column HP-5MS (30 m $\times$ $0.25 \mathrm{~mm}$ ), which film thickness was $0.25 \mu \mathrm{m}$. The source temperature and the injector temperature were 230 and $250{ }^{\circ} \mathrm{C}$, respectively. The temperature was programmed from $50{ }^{\circ} \mathrm{C}(2 \mathrm{~min})$ to $230{ }^{\circ} \mathrm{C}$ at $40{ }^{\circ} \mathrm{C} \cdot \mathrm{min}^{-1}$ and then to $250{ }^{\circ} \mathrm{C}$ at $10{ }^{\circ} \mathrm{C} \cdot \mathrm{min}^{-1}$ and then to $280{ }^{\circ} \mathrm{C}$ at $20{ }^{\circ} \mathrm{C} \cdot \mathrm{min}^{-1}$ (keeping this temperature for $10 \mathrm{~min}$ ). With split ratio $50: 1,0.20 \mu \mathrm{L}$ of sample was injected. Sulfuric acid and methanol solution (1:9 in volume) was applied as esterification reagent for the derivatization of oleic acid, stearic acid, phenyl stearic acid.

\section{The component of Daqing oil field simulated formation water}

Daqing oil field simulated formation water consists of $112.9 \mathrm{mg} \cdot \mathrm{L}^{-1} \mathrm{CaCl}_{2}, 43.6$ $\mathrm{mg} \cdot \mathrm{L}^{-1} \mathrm{MgCl}_{2}, 1582.0 \mathrm{mg} \cdot \mathrm{L}^{-1} \mathrm{NaCl}, 17.0 \mathrm{mg} \cdot \mathrm{L}^{-1} \mathrm{Na}_{2} \mathrm{SO}_{4}, 381.6 \mathrm{mg} \cdot \mathrm{L}^{-1} \mathrm{Na}_{2} \mathrm{CO}_{3}$ and $3175.2 \mathrm{mg} \cdot \mathrm{L}^{-1} \mathrm{NaHCO}_{3}$. The total dissolved substance is $5312.3 \mathrm{mg} \cdot \mathrm{L}^{-1}$.

3. The yield calculation of alkylation, decarboxylation, sulphonation and neutralization

The conversion of alkylation was calculated by a formula

$\eta=\frac{A_{\mathrm{R}} \times A_{\mathrm{I}}^{r}-A_{\mathrm{R}}^{v} \times A_{\mathrm{I}}}{A_{\mathrm{R}} \times A_{\mathrm{I}}^{r}}$

where $A_{\mathrm{R}}$ is the peak area of methyl oleate before the alkylation; $A_{\mathrm{R}}^{\prime}$ is the peak area of methyl oleate after the alkylation; $A_{\mathrm{I}}$ is the peak area of methyl stearate before the alkylation; $A_{\mathrm{I}}^{\prime}$ is the peak area of methyl stearate after the alkylation.

The conversion of decarboxylation was calculated as the ratio of the peak area for product and the sum peak area for both reactant and product after decarboxylation.

The conversion of sulphonation and neutralization was computed as the mole ratio of product and reactant by weighing method using a formula.

$\eta=\frac{316 \times m_{\mathrm{B}}}{418 \times m_{\mathrm{A}}}$

where, $m_{\mathrm{A}}$ and $m_{\mathrm{B}}$ are the weight of the reactant and product, respectively; 316 is the molecular weight of reactant; 418 is the molecular weight of product. 


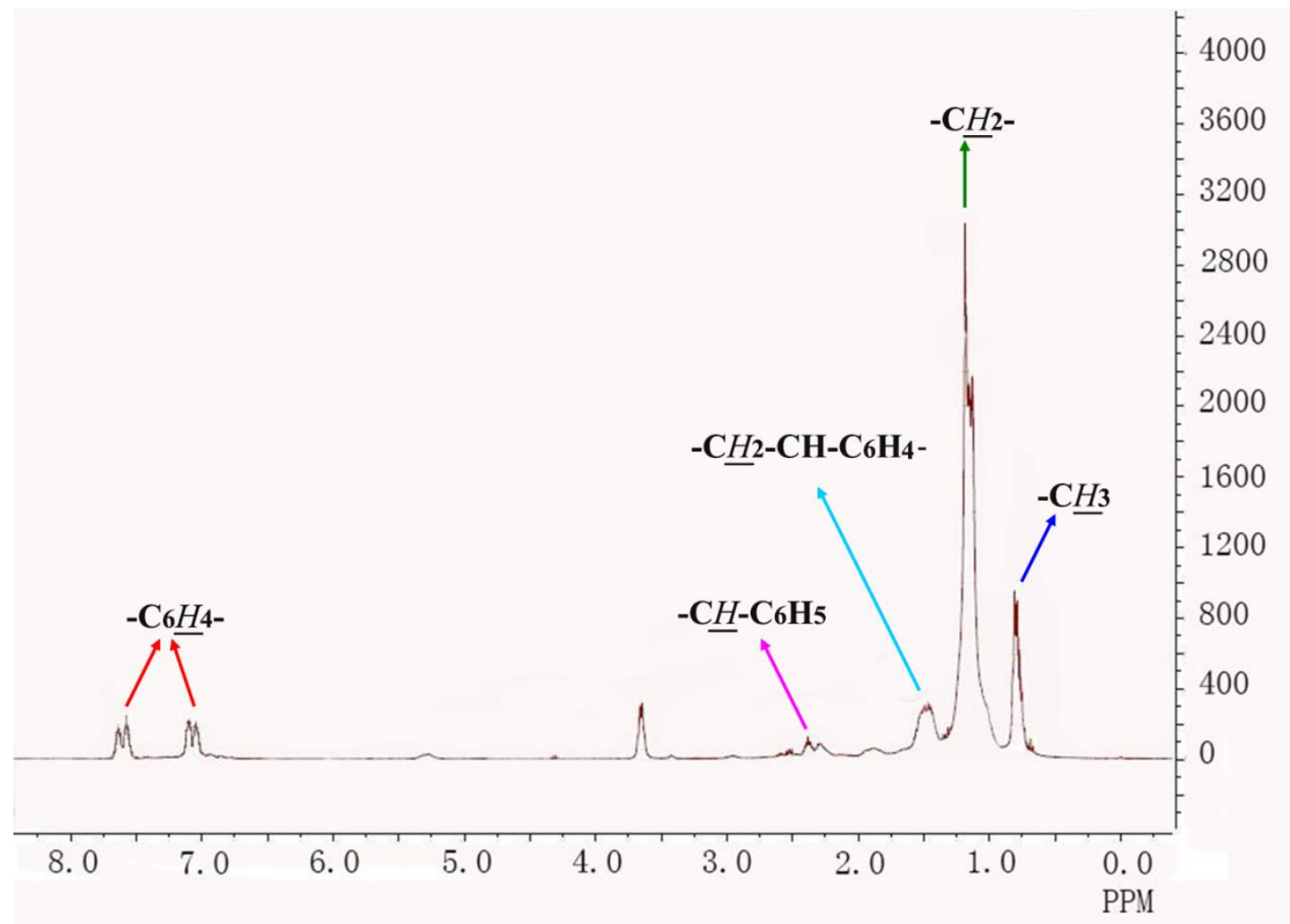

Fig.S1 H NMR spectrum of 9ФC17S

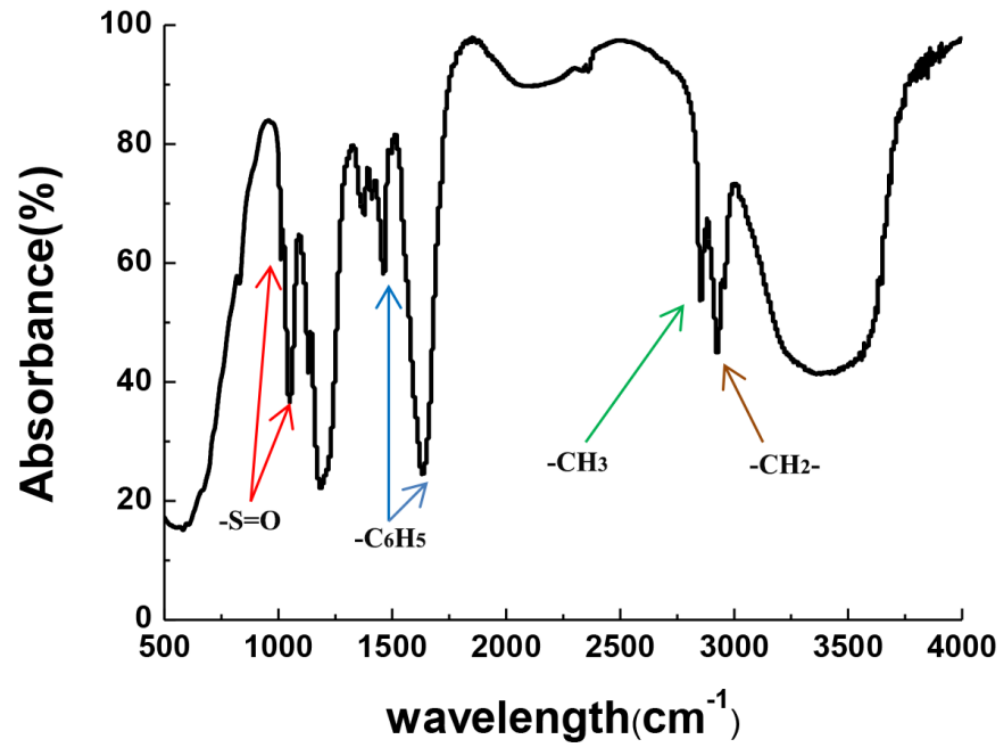

Fig.S2 Infrared spectroscopy of 9ФC17S 


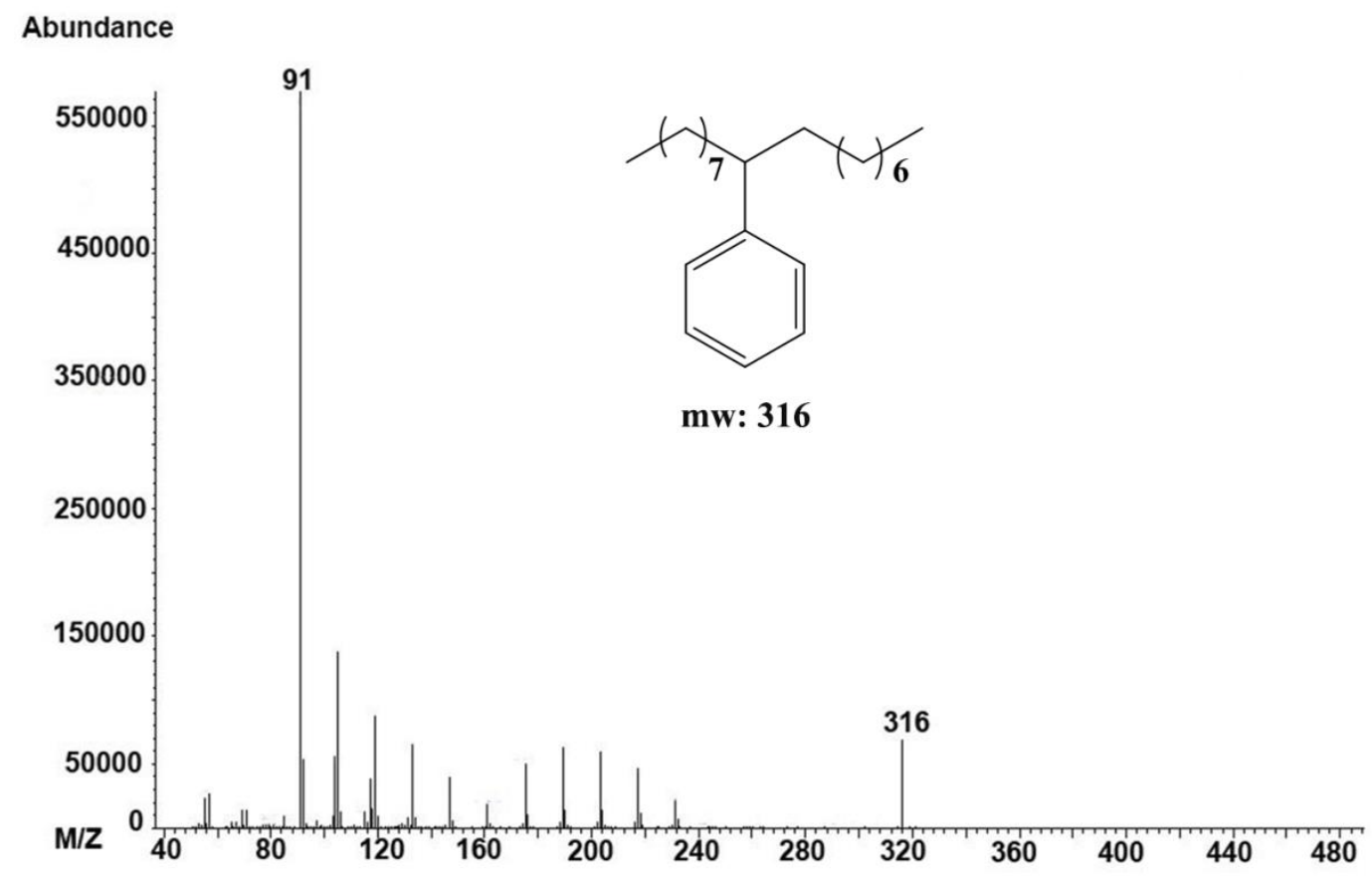

Fig.S3 Mass spectrum of heptadecylbenzene

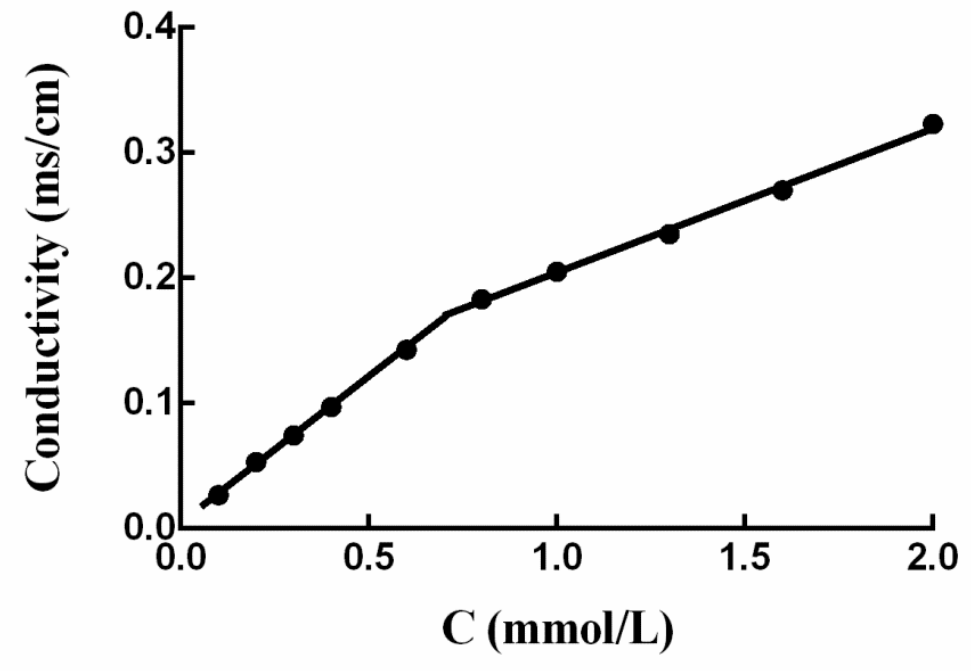

Fig.S4 Variation of the conductivity of $9 \Phi С 17 \mathrm{~S}$ solution with concentrations at $25{ }^{\circ} \mathrm{C}$ 


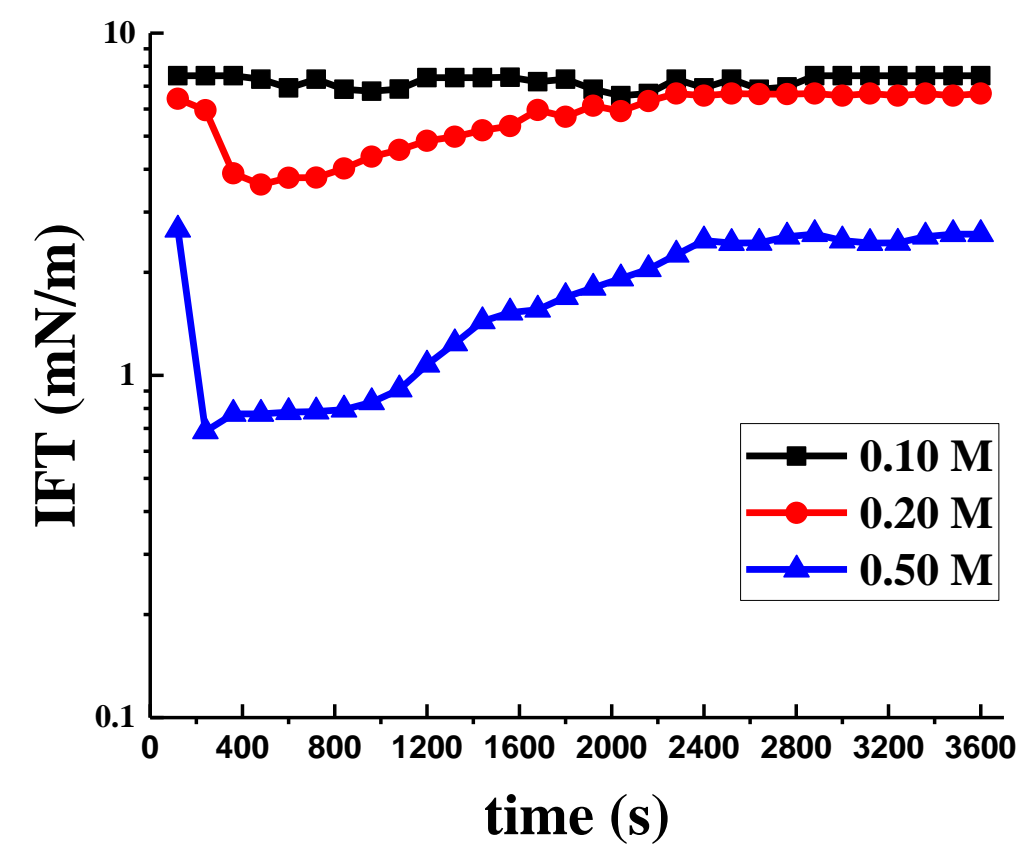

Fig.S5 Dynamic interfacial tensions between Daqing crude oil and different concentrations $\mathrm{Na}_{2} \mathrm{CO}_{3}$ solutions in simulated formation water at $50.0{ }^{\circ} \mathrm{C}$

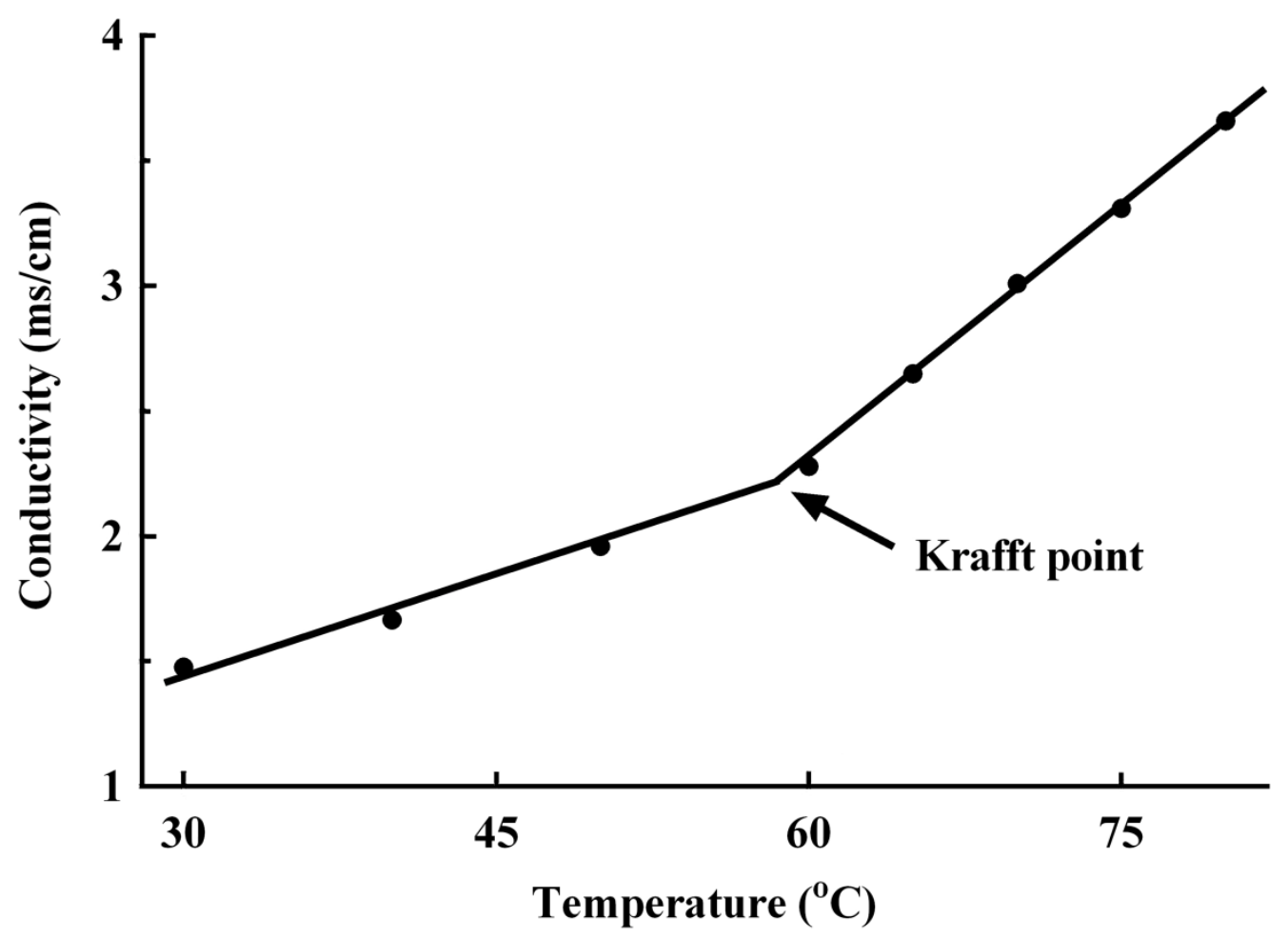

Fig.S6 Krafft point of 9ФC17S

Variation of the conductivity of $1 \% 9 \Phi C 17 \mathrm{~S}$ solution with the temperatures 